\title{
Anti Cancer Activity of Active Substances from Mangosteen pericarp (Garcinia mangostana Linn) against T47 D Cell Lines
}

\author{
Siti Rofida ${ }^{1 *}$, Sukardiman $^{2}$, Aty Widyawaruyanti ${ }^{2}$, and Lusiana Arifianti ${ }^{2}$ \\ ${ }^{I}$ Departement of Pharmacy, Faculty of Health Sciences, Muhammadiyah Malang University, \\ Indonesia \\ Jalan Bendungan Sutami 188 A, Kota Malang, Jawa Timur 65145 \\ ${ }^{2}$ Departement of Pharmacognocy and Phytochemical, Faculty of Pharmacy, Airlangga University, \\ Indonesia \\ Jalan Dharmawangsa No.4-6, Airlangga, Gubeng, Kota Surabaya, Jawa Timur 60286 \\ *Corresponding author: rofida.28879@gmail.com
}

\begin{abstract}
Background: Garcinia mangostana Linn (Guttiferae) or commonly know as mangosteen has been reported scientifically as anticancer. In developing a pericarp of G.mangostana as the anticancer phytopharmaceutical product, bioassay-guided fractionation approach was chosen to get active substances to be used as raw material breast-cancer drugs. Objectives:The aim of this study is to get the anticancer substances from the pericarp of G.mangostana that are active against breast cancer cells T47D. Method: Separation of active substances was carried out by column chromatography techniques. Based on the principle of bioassay-guided fractionation, a cytotoxicity assay of ethanolic extract and fractions was performed against T47D human breast cancer cell lines. Results:Cytotoxicity assay of the extract, fraction 2, subfraction 2.2, subfraction 2.2.4, and subfraction 2.2.4.4 provided $I_{50}$ values $8.96 \mathrm{ug} / \mathrm{mL} ; 1.80 \mathrm{ug} / \mathrm{mL} ; 1.76 \mathrm{ug} / \mathrm{mL} ; 1.12 \mathrm{ug} / \mathrm{mL}$; and 6.93 $u g / m L$ respectively
\end{abstract}

Keywords: Garcinia mangostana Linn, bioassay-guided fractionation, active substance against breast cancer

\section{INTRODUCTION}

Cancer is a disease which characterized by a change of control mechanism that regulates the proliferation and differentiation of cells. Mortality caused by cancer is approximately about $13 \%$ from all (WHO, 2012). Breast cancer is the type of cancer that is characterized by high level of mortality. Cancer treatments are aimed to treatment, prolong and improve patient quality of life.

Garcinia mangostana Linn or commonly known as mangosteen is a plant from Guttiferae family and have been used traditionally for the treatment of skin infections and wound, amoebic dysentery and inflammation (Chaverri et al. 2008; Chin \& Kinghorn 2008). These plants contain xanthone-type compounds, flavonoids, triterpenoids, benzophenones, biphenyl compounds, pyrrole, benzofuran, tannins, and saponins (Chaverri et al. 2008; Hutapea 1994). Anticancer research of G.mangostana pericarp ethanol extract using cultured human breast cancer cells (SKBR3) have been given the $\mathrm{IC}_{50}$ value of $15.45 \pm 0.5$ $\mathrm{ug} / \mathrm{ml}$ (Moongkarndi 2004). The Breast-cancer activity of $\gamma$-mangosteen and $\alpha$-mangosteen 
compounds using cultured human breast cancer cells (MCF-7) showed $\mathrm{IC}_{50}$ values of 0.85 and $10.5 \mu \mathrm{g} / \mathrm{ml}$, respectively (Ahmat et al. 2010, Chitra et al. 2010).

Based on the previous studies, the pericarp of G.mangostana has active compounds as anticancer and is prospective as a phytopharmaceutical product. In developed of G.mangostana pericarp into phytopharmaceutical product, then the study to get the active substances as raw material for breast cancer. The processes include extraction and fractionation. Based on the principle of bioassay-guided fractionation, a cytotoxicity assay of ethanolic extract and fractions against T47D human breast cancer cell lines were performed.

\section{METHOD}

\section{Materials and cell}

Ethanol, n-hexane, ethyl acetate, chloroform, methanol, dichloromethane, aqua bidest, silica gel 60 Merck 0,063-0,200 mm, silica gel 60 G Merck. Breast cancer cell lines T47D collected from Parasitology Laboratory, Medicine Faculty UGM, medium RPMI, fetal bovine serum $10 \%$, penicillin-streptomycin, 1\%, fungison 0,5\%, Phosphate Buffer Saline $20 \%$; Dimethyl sulfoxide; 3-(4,5-Dimetiltiazol-2-il)-2,5-diphenyltetrazolium bromide; Sodium Dodecyl Sulphate $10 \%$.

\section{Plant material}

Garcinia mangostana pericarp was obtained from Blitar.

\section{Fractionation}

5.5 Kg mangosteen's pericarp powder macerated using $14.5 \mathrm{~L}$ ethanol $96 \%$ for 48 hours. Then filtered and the filtrate was separated. The filtrate was collected and evaporated with a vacuum rotary evaporator to obtain a viscous extract which was dried in an oven at $40^{\circ}$ C. Separation used vacuum chromatography column method with stationary phase silica gel and the mobile phase gradient solvent hexane: ethyl acetate, chloroform: methanol, methanol, and ethanol in order to obtain 12 fractions. The results of cytotoxicity assay used T47D cells, proved that the fraction 2 was active. The next separation was performed on fraction 2 using open column chromatography with stationary phase silica, mobile phase gradient solvent hexane: ethyl acetate, ethyl acetate: chloroform, chloroform: methanol, and methanol to obtain 7 subfractions. The results of cytotoxicity assay used T47D cells, proved that the fraction 2 was active. Then, subfraction 2.2, separated by vacuum column chromatography used stationary phase silica, mobile phase gradient solvent hexane: dichloromethane, dichloromethane: ethyl acetate and methanol to obtain 8 subfractions. The results of cytotoxicity assay used T47D cells, proved that the fraction 2 was active. Further separation was performed on the SF2.2.4 with open column chromatography used stationary phase silica, mobile phase hexane: dichloromethane, dichloromethane: methanol and methanol to obtain 7 subfractions. The results of cytotoxicity assay used T47D cells, indicated that subfraktion 2.2.4.4 and 2.2.4.5 are active.

\section{Sample preparation}

The sample for cytotoxicity assay was dissolved in DMSO.

\section{Cell Viability}

Cells were distributed into 96 well of the plate and then were incubated in $5 \% \mathrm{CO}_{2}$ conditions at $37^{\circ} \mathrm{C}$ for overnight. Test solution with a certain concentration incorporated into cancer cell cultures $5 \times 10^{3}$ cells $/ \mathrm{ml}$ each well and were incubated under conditions of $5 \% \mathrm{CO}_{2}$ at $37{ }^{\circ} \mathrm{C}$ for 24 hours. The fluid was pipetted and was discarded for each well and then were rinsed 
with PBS solution then shacked and thrown away. $100 \mathrm{ml}$ of culture media were added to each well. Added $10 \mu \mathrm{l}$ solution of MTT into PBS at concentration $5 \mathrm{mg} / \mu \mathrm{l}$. Incubated under conditions of $5 \% \mathrm{CO}_{2}$ at $37^{\circ} \mathrm{C}$ for $4-6$ hours, then added stopper reagent (10\% SDS). Incubated overnight at room temperature and stored in the dark place. The spare was read by ELISA reader at 550-600 nm wavelengths.

\section{Statistical Analysis}

The percentage of live cells was calculated to obtain the $\mathrm{IC}_{50}$ value. The data were analyzed with probit analysis.

\section{RESULT AND DISCUSSION}

This study is one part of the process to develop mangosteen pericarp (Garcinia mangostana Linn.) into phytopharmaceutical products to treat breast cancer. Introduction and development of several new and highly specific in vitro bioassay techniques, chromatographic methods, and spectroscopic techniques have made it much easier to screen, isolate and identify the lead compound quickly and precisely.The drug discovery from natural materials could use bioassay-guided solation approach (Sarker et al. 2006). This research aims to obtain anticancer ingredients that originally are from Garcinia mangostana Linn pericarp which is active against human breast cancer cells T47D.

The first stage was extraction process. G. mangostana pericarp was chopped and dried in the oven at $50{ }^{\circ} \mathrm{C}$, then grounded into powder. $5.5 \mathrm{Kg}$ dried powder were macerated by ethanol. The macerate then vaporized using a rotary evaporator at $60^{\circ} \mathrm{C}$ to obtain a yellowish brown viscous extract.

TLC profiles at $254 \mathrm{~nm}$ UV light observations showed a dark brown color, the observation of $366 \mathrm{~nm}$ UV light showed brown, yellow, blue and purple stain. The plate then sprayed with $10 \%$ sulfuric acid and gave a yellow to brown colored stain. Flavonoids observed with UV will give a-characteristic colors such as yellow, orange, brown, blue and purple fluorescent (Harborne 1987). Meanwhile, phenolic compounds of carboxylic acid group observed with UV will also give a-characteristic colors such as yellow, brown, blue or turquoise fluorescent (Debenedetti 2009). The TLC densitometry analysis of the plate was conducted at $254 \mathrm{~nm}$ wavelength and showed 2-3 peaks in 250-500 nm area. This result indicated that the compound contained the conjugated aromatic group (Harborne 1987). The result of in vitro assay of $\mathrm{G}$. mangostana ethanolic extract against T47D breast cancer cells showed the $\mathrm{IC}_{50}: 8.96 \mu \mathrm{g} / \mathrm{mL}$ (Figure 1). According to the National Cancer Institute (NCI), the extracts that had $\mathrm{IC}_{50}$ values less than $20 \mu \mathrm{g} / \mathrm{mL}$ against cancer cell cultures could be considered effective as anticancer (Ampasavate et al. 2010). So based on the provision of the NCI, the ethanolic extract of G mangostana pericarp is effective as against breast cancer.

Bioassay guided isolation principle, as much as 7.5 grams of ethanol extracts were fractionated by vacuum column chromatography using silica gel G60 stationary phase with a mobile phase gradient of the solvent mixture of hexane and ethyl acetate, chloroform: methanol, methanol and finally $96 \%$ ethanol. The solvents had been used each gradient was $100 \mathrm{ml}$ and the fractions that collected and was combined based on similar TLC profiles, so were obtained 12 fractions with respective weights of $357.2 \mathrm{mg} ; 2639.7 \mathrm{mg}, 1093.4 \mathrm{mg}$, $477.2 \mathrm{mg} ; 298.5 \mathrm{mg}, 214.1 \mathrm{mg}, 181.6 \mathrm{mg} ; 1005.5 \mathrm{mg}, 393.8 \mathrm{mg}, 25.9 \mathrm{mg}, 10 \mathrm{mg}$ and $43 \mathrm{mg}$. 


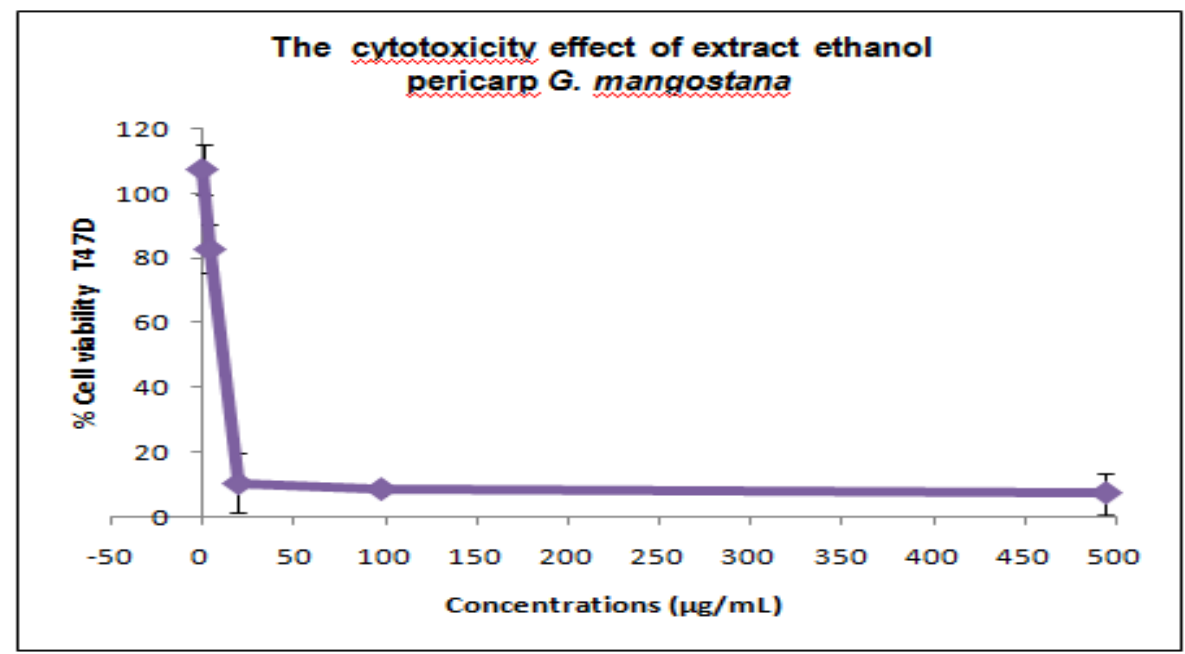

Figure 1 Cell viability T47D cell lines

Anticancer activity results of fractions $1-12$ as in vitro assay against T47D breast cancer cells, showed $\mathrm{IC}_{50}: 6.02 ; 1.80 ; 3.43 ; 6.09 ; 7.44 ; 10.44 ; 21.19 ; 411.52 ; 542.55$; $5746.05 ; 1005.62 ; 360.81 \mu \mathrm{g} / \mathrm{mL}$ (Figure 2). Based on provisions of the NCI, the fractions 16 were declared effective against breast cancer. Based on those data, further separation of the most active fraction of the fraction 2 with $\mathrm{IC}_{50}$ values of $1.80 \mu \mathrm{g} / \mathrm{mL}$ will be done.

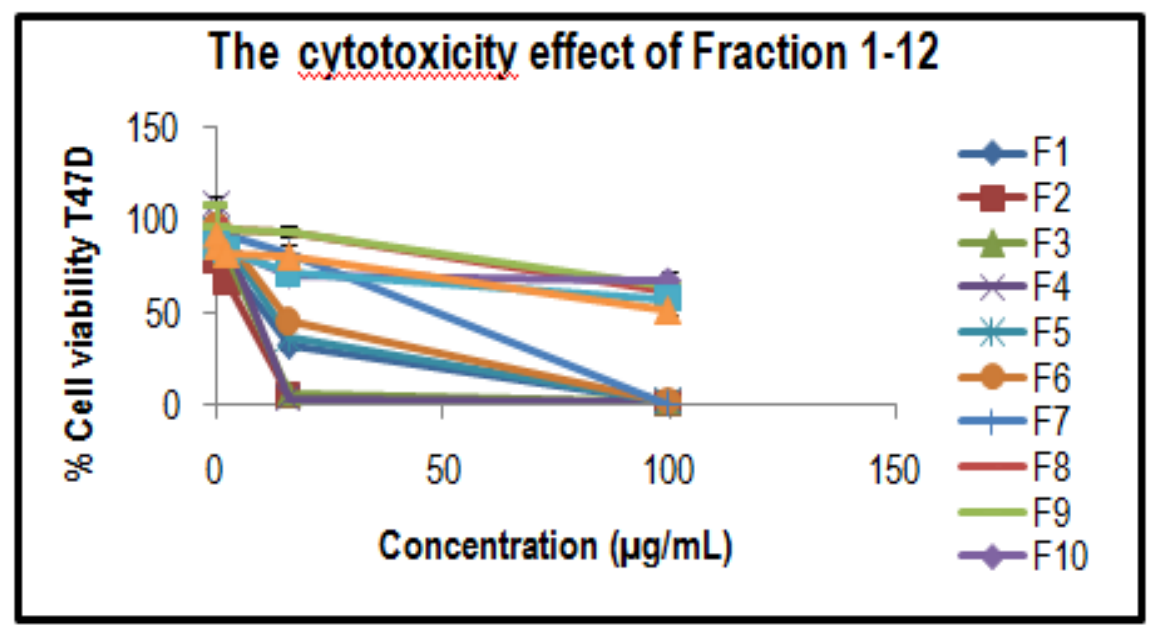

Figure 2 Cell viability T47D cell lines

Separation of the fraction 2 as much as 2 grams used an open column chromatography with the stationary phase silica gel 60 and the mobile phase gradient solvent mixture hexane: ethyl acetate, ethyl acetate: chloroform, chloroform: methanol and the last used methanol. Eluates were collected every $10 \mathrm{ml}$, fractions that collected were combined based on TLC profiles, thus obtained 7 subfractions with respective weights of $237.6 \mathrm{mg}, 736.5 \mathrm{mg}$, $278.6 \mathrm{mg}, 567.3 \mathrm{mg}, 45.3 \mathrm{mg} ; 9.4 \mathrm{mg}, 148.1 \mathrm{mg}$. Anticancer activity in vitro assay result of subfraction $1-7$ against T47D breast cancer cells, showed $\mathrm{IC}_{50}: 7.59 ; 1.76 ; 3.58 ; 4.46 ; 8.07$; 23.64; $31.75 \mu \mathrm{g} / \mathrm{mL}$ (Figure 3). Based on provisions of the NCI, the subfraction 2.1-2.5 were defineted as effective against breast cancer. Based on those data further separation of the most active subfraction the subfraction 2.2 with $\mathrm{IC}_{50}$ values of $1.76 \mu \mathrm{g} / \mathrm{mL}$ will be done. 


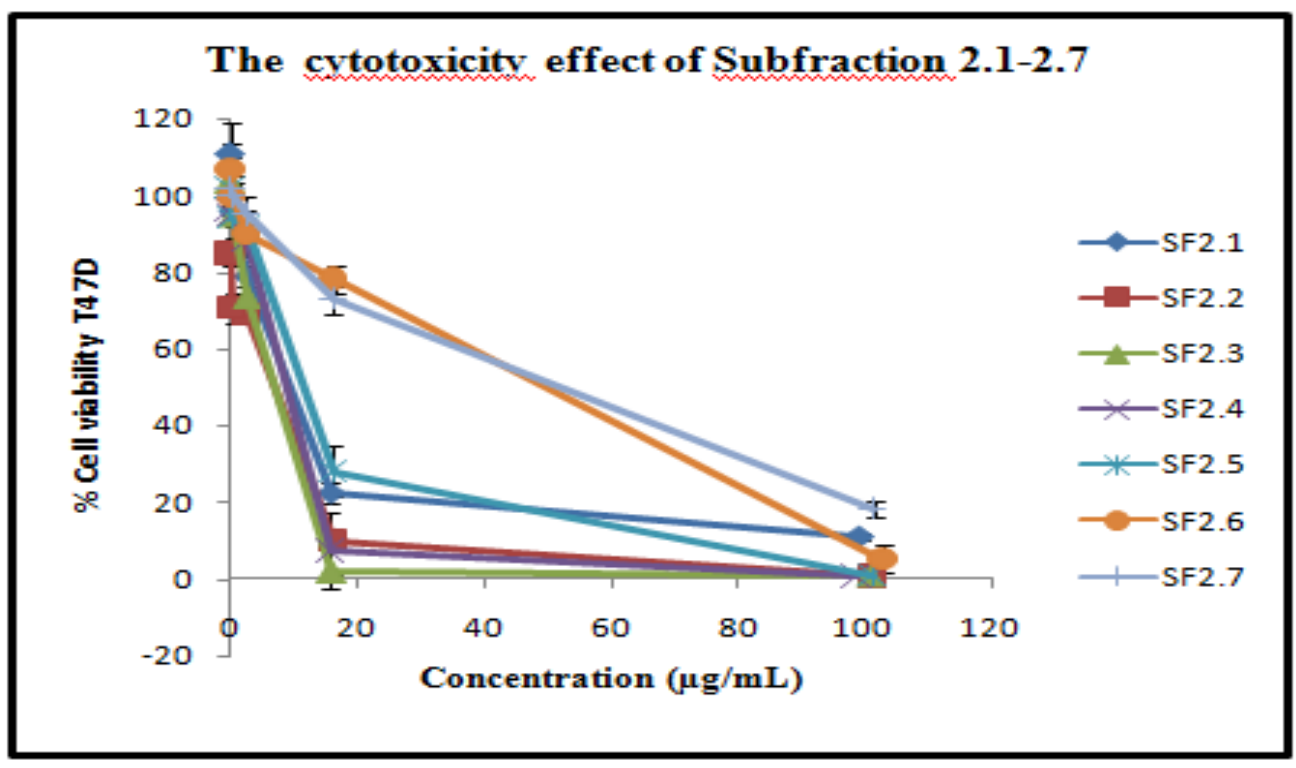

Figure 3 Cell viability T47D cell lines

Separation process of 1 gram subfraction 2.2 by vacuum column chromatography with the stationary phase silica gel G 60 and the mobile phase is a mixture of hexane solvent gradient and dichloromethane, then mixed dichloromethane and ethyl acetate and the last used methanol. The solvent was used in each gradient was $10 \mathrm{ml}$ and fractions were collected and were combined based on similar TLC profiles, so obtained 8 subfractions with respective weights of $10.7 \mathrm{mg}, 29.5 \mathrm{mg}, 8.0 \mathrm{mg}, 283.0 \mathrm{mg}, 454.4 \mathrm{mg}, 30.0 \mathrm{mg}, 21.0 \mathrm{mg}, 4.6$ $\mathrm{mg}$. Anticancer activity in vitro assay results of subfraction 2.2.1-2.2.8 against T47D breast cancer cells showed $\mathrm{IC}_{50}$ values of $5.33 ; 3.14 ; 5.79 ; 1.12 ; 2.54 ; 4.72 ; 3.13 ; 10.86 \mu \mathrm{g} / \mathrm{mL}$ respectively (Figure 4). Based on provisions of the NCI, the fractions 2.2.1-2.2.8 were declared as effective against breast cancer. Based on those data further separation of the most active subfraction the subfraction 2.2.4 with IC ${ }_{50}$ values of $1.12 \mu \mathrm{g} / \mathrm{mL}$ was done.

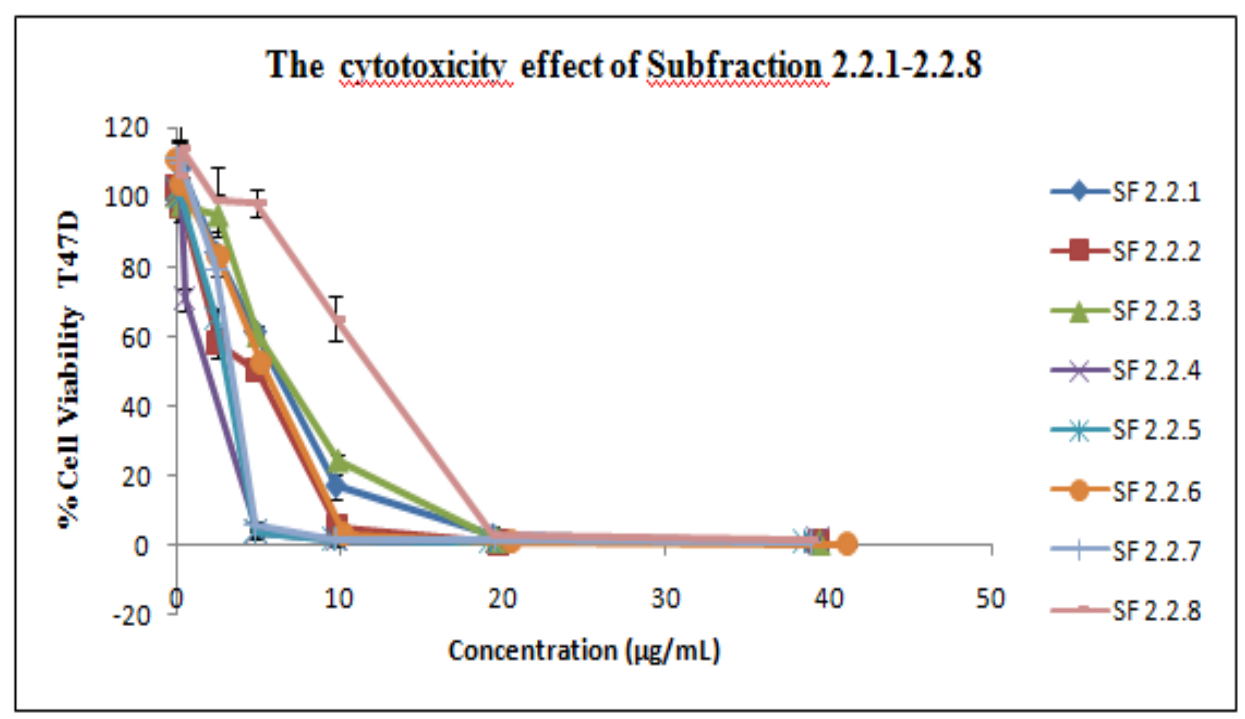

Figure 4 Cell viability T47D cell lines

Against subfraction 2.2.4 as much as $100 \mathrm{mg}$, had been separated by using an open column chromatography with stationary phase silica gel 60 and the mobile phase gradient solvent hexane: dichloromethane, dichloromethane: methanol and 100\% methanol. Eluates were collected every $1 \mathrm{ml}$, fractions that collected were combined based on TLC profiles, so 
obtained 7 subfractions with respective weights of $15.4 \mathrm{mg}, 3.5 \mathrm{mg}, 13.2 \mathrm{mg}, 9.4 \mathrm{mg}, 24 \mathrm{mg}$; $16.2 \mathrm{mg}, 11.3 \mathrm{mg}$. Anticancer activity in vitro assay results of subfraction 2.2.4.1-2.2.4.7 against T47D breast cancer cells showed IC $_{50}$ values amounted to $694.95 ; 324.62 ; 190.30$; $6.93 ; 7.97 ; 98.87 ; 198.97 \mu \mathrm{g} / \mathrm{mL}$ (Figure 5). Based on provisions of the NCI, the subfractions 2.2.4.4 and 2.2.4.5 were declared as effective against breast cancer. Subfraction 2.2.4.4 and 2.2.4.5 had anticancer activity not too different, as shown by the $\mathrm{IC}_{50}$ values at 6.93 and 7.97 $\mu \mathrm{g} / \mathrm{mL}$. The results of TLC subfractions 2.2.4.4 and 2.2.4.5 indicated that the profiles have no significant differences showed by dominant stains on Rf value 0.31 and 0.34 of each.

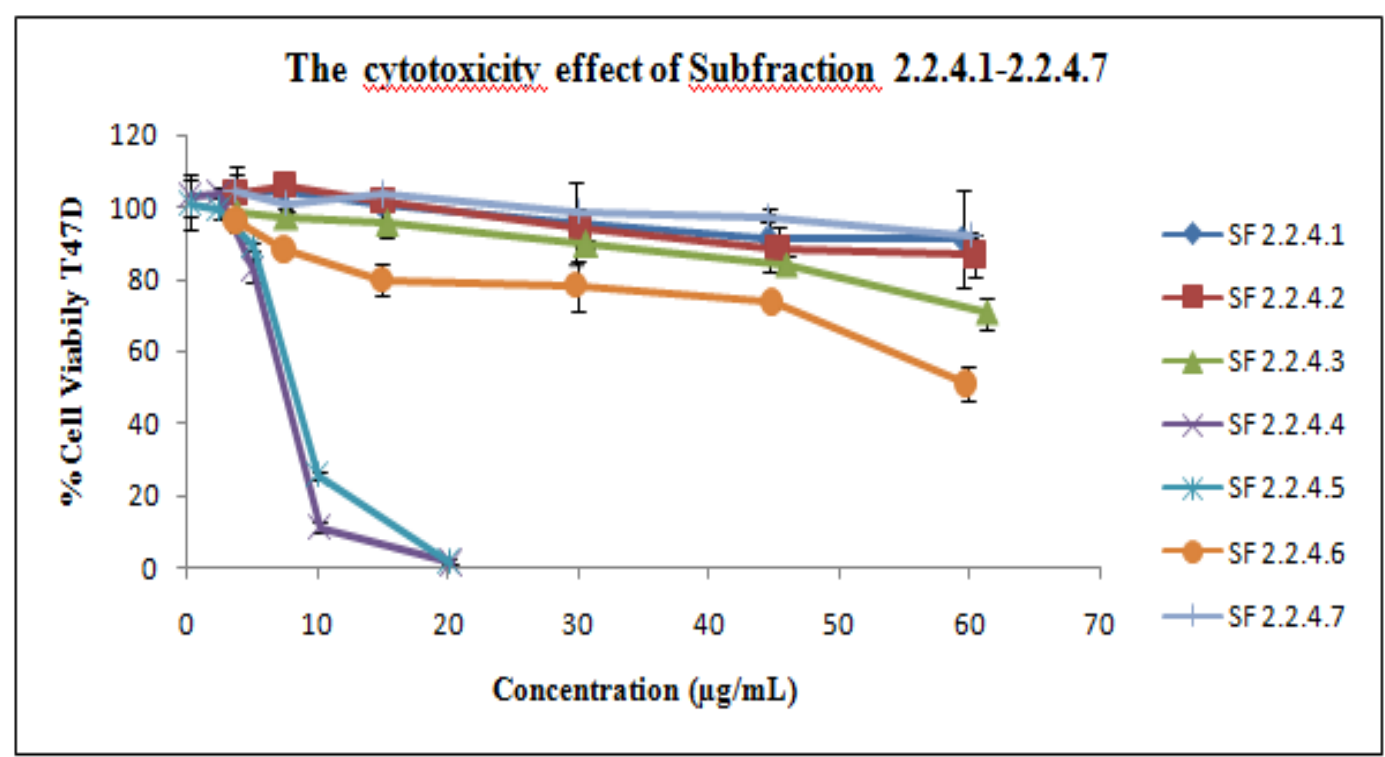

Figure 5 Cell viability T47D cell lines

The results of anti-breast-cancer activity assay showed that the ethanolic extract of $G$. mangostana pericarp and some fractions were effective against T47D breast cancer cell lines. The $\mathrm{IC}_{50}$ values are $8.96 \mu \mathrm{g} / \mathrm{mL}$ for ethanolic extract; $1.80 \mu \mathrm{g} / \mathrm{mL}$ for $\mathrm{F} 2 ; 1.76 \mu \mathrm{g} / \mathrm{mL}$ for SF2.2; $1.12 \mu \mathrm{g} / \mathrm{mL}$ for SF2.2.4 and $6.93 \mu \mathrm{g} / \mathrm{mL}$ for SF2.2.4.4. Bioactivity-guided fractionation result of the ethanol extract until had been obtained SF.2.2.4 showed the decrease in $\mathrm{IC}_{50}$ values. It's showed that from this separation process was obtained the fraction which had compounds that were responsible for the breast-cancer activity. However, there was an odd phenomenon when the further separation was done to SF 2.2.4 producing $\mathrm{SF}$ 2.2.4.4 as subfraction product. The $\mathrm{IC}_{50}$ value of SF 2.2.4.4 was higher than its mother fraction SF 2.2.4. This phenomenon also occurred in the research that had been done by Widyawaruyanti (2007) and Tumewu (2009) about the antimalarial activity of Cempedak bark (Artocarpus champeden SPRENG). From those studies was known that Cempedak bark ethanol extract and fraction 4 which from the separation of the ethanol extract, could inhibit in vitro of Plasmodium falciparum growth at IC ${ }_{50}$ values at $1.90 \mu \mathrm{g} / \mathrm{mL}$ and $6.69 \mu \mathrm{g} / \mathrm{mL}$, respectively.

In general, the activity of the active component would provide good results because it has inert compound (Yadav \& Dixit 2008). This inert compound does not affect the mechanism of pathology directly, but these compounds may affect the bioavailability and the excretion of the active compounds, which leads to the increasing of the active compounds stability and decreasing of the side effects. 


\section{CONCLUSION}

Anticancer substances derived from Garcinia mangostana Linn pericarp which are active against human breast cancer cells T47D are ethanol extract, fraction 2, subfraction 2.2, subfraction 2.2.4 and subfraction 2.2.4.4.

\section{REFERENCES}

Ahmat, N., Azmin, N.F.N., Ghani, N.A., Aris, S.R.S., Sidek, N.J., Abdullah, S., Jasmani, H., Bioactive Xanthones from the Pericarp of Garcinia mangostana. Middle-East Journal of Scientific Research, 2010, 6(2):123-127.

Ampasavate, C., Okonogi, S., Anuchapreeda, S., Cytotoxic of extracts from fruit plants against leukemic cell lines. African Journal of Pharmacy and Pharmacology, 2010, 4(1):13-21.

Chaverri, J.P., Rodriguez, N.C., Ibarra, M.O., Rojas, J.M.P., Medicinal properties of mangosteen (Garcinia mangostana). Food and Chemical Toxicology, 2008, 46: 32273239.

Chin, Y.W., Kinghorn, A.D., Structural Characterization, Biological Effect, and Synthetic Studies on Xanthones from Mangosteen (Garcinia mangostana), a Popular Botanical Dietary Supplement. Organic Chemistry, 2008, 4(4): 355-364.

Chitra, S., Krithika M.V., Pavithra, S., Induction of Apoptosis by Xanthones from Garciniamangostanain Human Breast Cancer and Laryngeal Carcinoma Cell Lines.International Journal of Pharma and Bio Sciences, 2010, 1(3):1-8.

Debenedetti, S.L., TLC and PC. In: Sampietro, D.A., Catalan, C.A.N., Vattuone, M,A., Narwal, S.S., (Eds). Isolation, Identification and Characterization of Allelochemical/ Natural Products. NewHampshire: Science Publishers, 2009, p: 103-134.

Departemen Kesehatan Republik Indonesia, 2000. Parameter Standar Umum Ekstrak Tumbuhan Obat. Jakarta: Departemen Kesehatan RI.

Harborne JB, Metode Fitokimia: Penuntun Cara Modern Menganalisis Tumbuhan (Terjemahan Kosasih P dan Iwang S), Ed 2, Bandung: Institut Teknologi Bandung, 1987, 234-259.

Hutapea, J.R., Inventaris Tanaman Obat Indonesia (III), Jakarta: Badan Penelitian dan Pengembangan Kesehatan Departemen Kesehatan Republik Indonesia, 1994, hal.69.

Moongkarndi, P., Kosem, N., Kaslungka, S., Luanratana, O., Pongpan, N., Neungton, N., Antiproliferation, antioxidation and induction of apoptosis by Garcinia mangostana (mangosteen) on SKBR3 human breast cancer cell line. Journal of Ethnopharmacology, 2004, 90:161-166.

National Cancer Institute, 2012, Breast Cancer.

Sarker, S.D., Latif, Z., Gray, A.I., An Overview of Natural Product Isolation. In: Sarker, S.D., Latif, Z., Gray, A.I. (Eds). Natural Products Isolation, Ed. $2^{\text {nd }}$, Totowa: Humana Press Inc., 2006, p:1-26.

Tumewu, L., Kajian Komponen Marker Ekstrak Kulit Batang Artocarpus champeden SPRENG. sebagai Bahan Baku Sediaan Fitofarmaka Antimalaria,Tesis, 2009, Program Magister Ilmu Farmasi Fakultas Farmasi Universitas Airlangga, Surabaya.

Widyawaruyanti A, Potensi dan Mekanisme Antimalaria Senyawa Flavonoid Hasil Isolasi dari Kulit Batang Artocarpus champeden Spreng., Disertasi, 2007, Program Pasca Sarjana Universitas Airlangga Surabaya.

World Health Organization, Cancer mortality and morbidity. http://www.who.int/gho/ncd/mortality_morbidity/cancer/en/index.html. [03/15/2012]. 
World Health Organization, Cancer. http://www.who.int/mediacentre/ factsheets/fs297/en/, [03/15/2012].

Yadav, N.P., Dixit, V.K., Recent approaches in herbal drug standardization. International Journal of Integrative Biology, 2008, 3(2):195-203. 